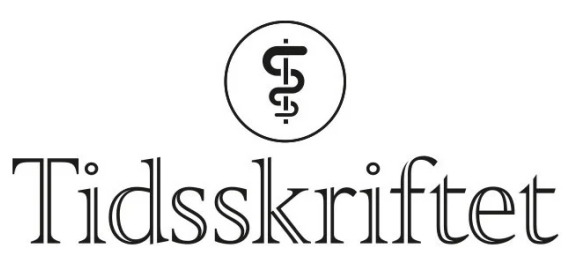

DEN NORSKE LEGEFORENING

\title{
Overvekt hos barn - hvilken betydning har bosted?
}

ORIGINALARTIKKEL

\section{NORA HEYERDAHL}

Nora Heyerdahl (f. 1986) har mastergrad i folkehelsevitenskap og arbeider i Avdeling for helsestatistikk ved Nasjonalt folkehelseinstitutt .

Forfatter har fylt ut ICMJE-skjemaet og oppgir ingen interessekonflikter.

Email: nora.heyerdahl@fhi.no

Divisjon for epidemiologi

Nasjonalt folkehelseinstitutt

og

Institutt for matematiske realfag og teknologi

Universitetet for miljø- og biovitenskap

\section{GEIR AAMODT}

Geir Aamodt (f. 1962) er siv.ing. og har doktorgrad i statistikk. Han er seniorforsker ved Folkehelseinstituttet og er professor II ved Universitetet for miljø- og biovitenskap.

Forfatter har fylt ut ICMJE-skjemaet og oppgir ingen interessekonflikter.

Divisjon for epidemiologi

Nasjonalt folkehelseinstitutt

og

Institutt for matematiske realfag og teknologi

Universitetet for miljø- og biovitenskap

\section{RANNVEIG NORDHAGEN}

Rannveig Nordhagen (f. 1933) er dr.med. og spesialist i immunologi og transfusjonsmedisin. Hun er seniorforsker ved Avdeling for arv og miljø, Nasjonalt folkehelseinstitutt. Forfatter har fylt ut ICMJE-skjemaet og oppgir ingen interessekonflikter.

Divisjon for epidemiologi

Nasjonalt folkehelseinstitutt

\section{RAGNHILD HOVENGEN}

Ragnhild Hovengen (f. 1948 ) er sykepleier/helsesøster og har mastergrad i Science in Public Health. Hun har hatt virke på ulike nivåer i den forebyggende helsetjenesten og innen fagutvikling og forskning. Siden 1997 har hun vært seniorrådgiver på Folkehelseinstituttet og er nå prosjektleder i studien Barns vekst i Norge.

Forfatter har fylt ut ICMJE-skjemaet og oppgir ingen interessekonflikter.

Divisjon for epidemiologi

Nasjonalt folkehelseinstitutt 
Målrettet forebygging av overvekt hos barn krever kunnskap om miljøfaktorer som har betydning. Vi ønsket å undersøke om overvekt hos norske tredjeklassinger har sammenheng med om disse bor i urbane eller rurale områder.

\section{MATERIALE OG METODE.}

I tverrsnittstudien Barns vekst $i$ Norge 2008 ble vekt, høyde og livvidde målt hos 3473 tredjeklassinger. Ved bruk av regresjonsanalyser undersøkte vi sammenhenger mellom overvekt og livvidde og sentralitet, bosettingstetthet og antall innbyggere i barnas hjemkommuner.

\section{RESULTATER}

I justerte analyser hadde barn i sentrale kommuner $34 \%$ mindre odds for overvekt sammenliknet med barn i lite sentrale kommuner ( $\mathrm{OR}=0,66 ; 95 \% \mathrm{KI}$ o,46-0,94). Barn i kommuner med høy bosettingstetthet gjennomsnittlig o,66 cm lavere livvidde enn barn i kommuner med lav bosettingstetthet ( $95 \% \mathrm{KI}$ o,02-1,31). Sammenhengen mellom overvekt og bosettingstetthet og innbyggertall og mellom livvidde og sentralitet og innbyggertall viste samme tendens, men var ikke statistisk signifikante i de justerte analysene.

\section{FORTOLKNING.}

Resultatene tyder på at det er en høyere andel barn med overvekt i rurale områder enn i urbane områder. Utdanning og inntektsnivå i kommunene så ut til å forklare noe av urbanitetsvariablenes effekt på overvekt og livvidde.

\section{Tabell}

\begin{tabular}{|l|}
\hline Hovedbudskap \\
\hline - Andelen overvektige barn var høyere i rurale enn i urbane kommuner \\
- Sammenhengen mellom urbanitet og overvekt kunne delvis forklares med \\
sosioøkonomiske forhold \\
av overvekt hos barn på landsbygda
\end{tabular}

Andelen barn med overvekt og fedme har $\emptyset \mathrm{kt}$ i store deler av verden $(\underline{2}, 3)$. I noen studier synes denne økningen nå å avta, men prevalensen er fortsatt høy $(4,5)$. Blant norske niåringer har 18,5 \% overvekt eller fedme (ㅁ). Overvekt og fedme medfører $\emptyset \mathrm{kt}$ risiko for sykelighet både blant barn og voksne (7.). Spesielt sentral fedme hos barn øker risikoen for hjerte- og karsykdom (모). Livvidde kan gi mer informasjon om kroppsmassefordeling enn kroppsmasseindeks (BMI) alene (9). Det er ikke utarbeidet internasjonale standarder for sykdomsrisiko hos barn $(7, \underline{10})$, men livvidde kan likevel brukes som indikator på sentral fedme i epidemiologiske studier (7.).

Overvekt og fedme i barndommen kan følge individet i voksenlivet $(\underline{11}, \underline{12})$ og få store $\emptyset$ konomiske følger for samfunnet (13). Det er i barndommen muligheten til å forebygge overvekt og fedme i voksen alder antakelig er størst $(.7,14$.$) . Overvekt er knyttet til ubalanse$ mellom energiinntak og energiforbruk (15), og gener og miljøfaktorer påvirker denne balansen $(7, \underline{11}, \underline{16})$. Målrettet forebygging krever kunnskap om hvilke miljøfaktorer som har betydning $(\underline{17}, \underline{18})$. 
I studier fra Norge og andre land er det vist sosioøkonomiske forskjeller i overvekt hos barn $(5, \underline{17}, \mathbf{1 9})$.)-(21). Vilimas og medarbeidere fant at forekomsten av overvekt i Oslo varierte mellom ulike bydeler (르). Det er funnet geografiske forskjeller i overvekt hos svenske og kanadiske barn $(\underline{23}, \underline{24}$ ), og i Norge er det observert høyere forekomst av overvekt hos 15-16åringer fra de nordligste fylkene og Oppland og Hedmark sammenliknet med ungdommer fra Oslo (17.). Sammenhengen mellom overvekt hos barn og urbanitet er ikke blitt undersøkt i Norge, men studier fra andre land har vist at overvekt hos barn er mer utbredt i rurale områder sammenliknet med urbane områder $(\underline{20}, \underline{25})$. I en kronikk i Aftenposten etterlyste Flø og medarbeidere problematisering av bygdebarnas oppvekst og mytene om

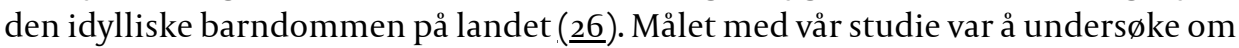
overvekt hos norske tredjeklassinger har sammenheng med om disse bor i urbane eller i rurale områder. Studiens to delmål var:

- å beskrive variasjoner i livvidde og andel barn med overvekt sett i forhold til sentralitet, bosettingstetthet og innbyggertall i barnas hjemkommuner

- å undersøke sammenhenger mellom overvekt og livvidde og de valgte kommuneegenskapene.

\section{Materiale og metode}

Datamaterialet er hentet fra Folkehelseinstituttets tverrsnittstudie Barns vekst $i$ Norge 2008 (27.) og består av målinger av 3511 tredjeklassinger fra 127 ulike skoler i 86 kommuner i ti fylker. Utvalget ble trukket av Statistisk sentralbyrå (SSB) som benyttet en tostegs geografisk klyngeutvalgsmodell, slik at ti tilfeldige fylker ble trukket fra fem geografiske strata tilsvarende de fem helseregionene. Fra hvert av de ti fylkene ble det trukket et tilfeldig utvalg av skoler. Alle 3-klassingene ved skolene i utvalget ble rekruttert. Studiens svarprosent var 89 . Kun $1 \%$ nektet deltakelse, og $10 \%$ deltok ikke på grunn av fravær fra skolen på måledagen eller at samtykke ikke var levert etter én purring. Data for høyde, vekt og livvidde var tilgjengelig for 3473 deltakere.

Datainnsamlingen ble gjennomført av skolenes helsesøstre i oktober og november 2008. Før innsamlingen fikk helsesøstrene opplæring i prosedyrene og utlevert metodebok for måling av høyde, vekt, livvidde og kontroll av vekter og høydemålere. Skolens vekter og høydemålere ble kontrollert mot et fast mål. Elevene ble målt én og én i skoletiden.

VARIABLER

Kroppsmasseindeks (BMI) ble beregnet fra innsamlede vekt- og høydedata (vekt i $\left.\mathrm{kg} / \mathrm{h} ø y d e m e t e{ }^{2}\right)$. Datamaterialet er korrigert for påkledning. Lett innetøy og tyngre påkledning er det korrigert for - med henholdsvis $100 \mathrm{~g}$ og $500 \mathrm{~g}$.

Vi undersøkte BMI som kontinuerlig variabel og andel barn med overvekt som kategorisk variabel. I artikkelen er fokuset på andel med overvekt. Med overvekt menes BMI $\geq 25$ etter

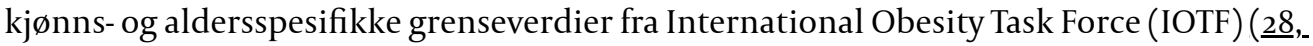
29.). Barnets nøyaktige alder ved undersøkelsestidspunktet ble brukt for å plassere barna i alderskategorier for hvert halvår.

Livvidden ble målt midt mellom øverste laterale kant av høyre hoftekam og nedre del av laterale ribbebue og ble inkludert som en kontinuerlig utfallsvariabel.

Urbanitet ble uttrykt ved kommuners sentralitet, bosettingstetthet og antall innbyggere. Etter det vi vet, finnes det ingen alminnelig anerkjente mål på urbanitet i Norge, og vi har valgt disse tre variablene som vi mener gir informasjon om ulike forhold som betegner kommunenes urbanitet.

Sentralitetsvariabelen beskriver kommuners beliggenhet i forhold til et sted med sentrale funksjoner. Den ble beregnet av Statistisk sentralbyrå, og kategoriene var lav, middels og høy sentralitet (30). 
Bosettingstetthet og innbyggertall i kommunen ble delt inn i to grupper hver for å skille mellom kommuner med høy og lav bosettingstetthet og høyt og lavt innbyggertall. Vi dikotomiserte variablene for å undersøke forskjeller i overvekt mellom grupper av kommuner med ulik urbanitet fremfor å se på lineære sammenhenger. Bosettingstetthet ble hentet fra Statistisk sentralbyrå og uttrykker den andel av befolkningen i en kommune som bor i tettbygd område. Vi delte kommunene inn i to kategorier avhengig av om de var over eller under medianverdien til bosettingstettheten for alle kommunene. Innbyggertall er det totale antallet innbyggere i hver kommune per 2008 (Statistikkbanken). Også denne variabelen ble dikotomisert. Etter det vi vet, finnes det ingen definerte grenseverdier for hva som i norsk sammenheng er høyt innbyggertall i en kommune, og grensen mellom høyt og lavt innbyggertall ble i studieprotokollen satt ved 10 ooo.

Sammenhengen mellom sosioøkonomisk status og overvekt hos barn er godt dokumentert $(5,7$.$) , og sosioøkonomisk status er en potensielt konfunderende faktor i sammenhengen$ mellom utfallsvariablene og sentralitet, bosettingstetthet og innbyggertall. Vi inkluderte derfor inntekts- og utdanningsnivå i kommunene i analysene $\mathrm{i}$ mangel av slike opplysninger på individnivå. Gjennomsnittlig inntekt i kommunene ble hentet som en kontinuerlig variabel fra Norsk samfunnsvitenskapelig datatjenestes (NSD) kommunedatabase for 2003. Kommuners utdanningsnivå ble hentet som en kontinuerlig variabel fra Statistikkbanken, med tall fra 2008. Kommunenes inntekts- og utdanningsnivå ble dikotomisert avhengig av medianverdiene i de kontinuerlige variablene.

Forklaringsvariablene, som var på kommunenivå, ble koblet til hver deltaker ut ifra hvilken kommune deltakerens skole tilhørte.

\section{STATISTISKE ANALYSER}

Barnas alder og de ulike utfallsvariablene med gjennomsnitt og andeler fordelt på kjønn fremgår av e-tabell 1 (207.).

\section{Tabell 1}

Alder, høyde, vekt, BMI og utfallsvariabler for gutter og jenter i studien Barns vekst i Norge 2008

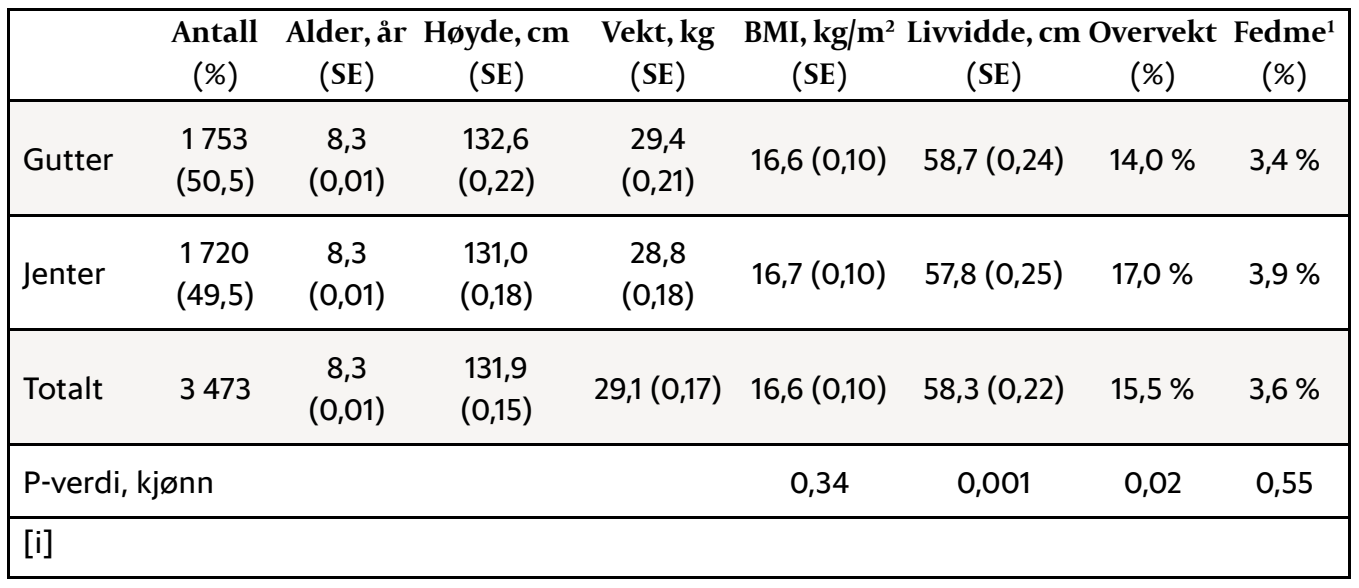

$[i]^{1}$ Med fedme menes BMI 30 etter kjønns- og aldersspesifikke grenseverdier fra International Obesity Task Force (IOTF)

Vi undersøkte sammenheng mellom overvekt og kommunevariabler, livvidde og kommunevariabler samt BMI og kommunevariabler. Lineære sammenhenger mellom forklaringsvariablene ble undersøkt med Pearsons korrelasjonskoeffisient. For å undersøke sammenhenger mellom grupper anvendte vi khikvadrattest, t-tester og ANOVA-tester. 
De avhengige variablene var både kontinuerlige (livvidde og BMI) og dikotome (BMI over og under 25), og vi brukte lineær og logistisk regresjon. Vi inkluderte de potensielt konfunderende faktorene inntekt og utdanning på kommunenivå samt barnets alder $\mathrm{i}$ modellene, uavhengig av om disse var statistisk signifikant assosiert med utfallene i univariable analyser. Det ble tatt høyde for utvalgsmetoden i alle analyser. Vi brukte STATA for å utføre våre statistiske analyser.

ETIKK

Undersøkelsen Barns vekst $i$ Norge er godkjent av Regional etisk komité. Elevenes foreldre ga informert skriftlig samtykke til at deres barn deltok.

\section{Resultater}

\section{KORRELASJONER}

Det var høy korrelasjon mellom de uavhengige variablene. Sterkest korrelert var bosettingstetthet og inntekt $(0,68)$, sentralitet og antall innbyggere $(0,62)$ og bosettingstetthet og sentralitet $(0,57)$. Lavest korrelasjon var mellom utdanning og antall innbyggere (o,37). Korrelasjonen mellom utdanning og inntekt var o,43.

\section{OVERVEKT OG KOMMUNEEGENSKAPER}

Tabell 2 viser resultater for overvekt. I første tallkolonne viser vi andelen av barna med overvekt i de ulike kategoriene. I univariable analyser fant vi at lav sentralitet eller lavt innbyggertall var statistisk signifikant assosiert med overvekt for begge kjønn. Bosettingstetthet hadde statistisk grensesignifikant sammenheng med overvekt bare hos jenter.

\section{Tabell 2}

Sammenheng mellom overvekt hos 3. klassinger og sentralitet, bosettingstetthet og antall innbyggere fra logistisk regresjonsmodell. Barns vekst i Norge 2008, N = 3473

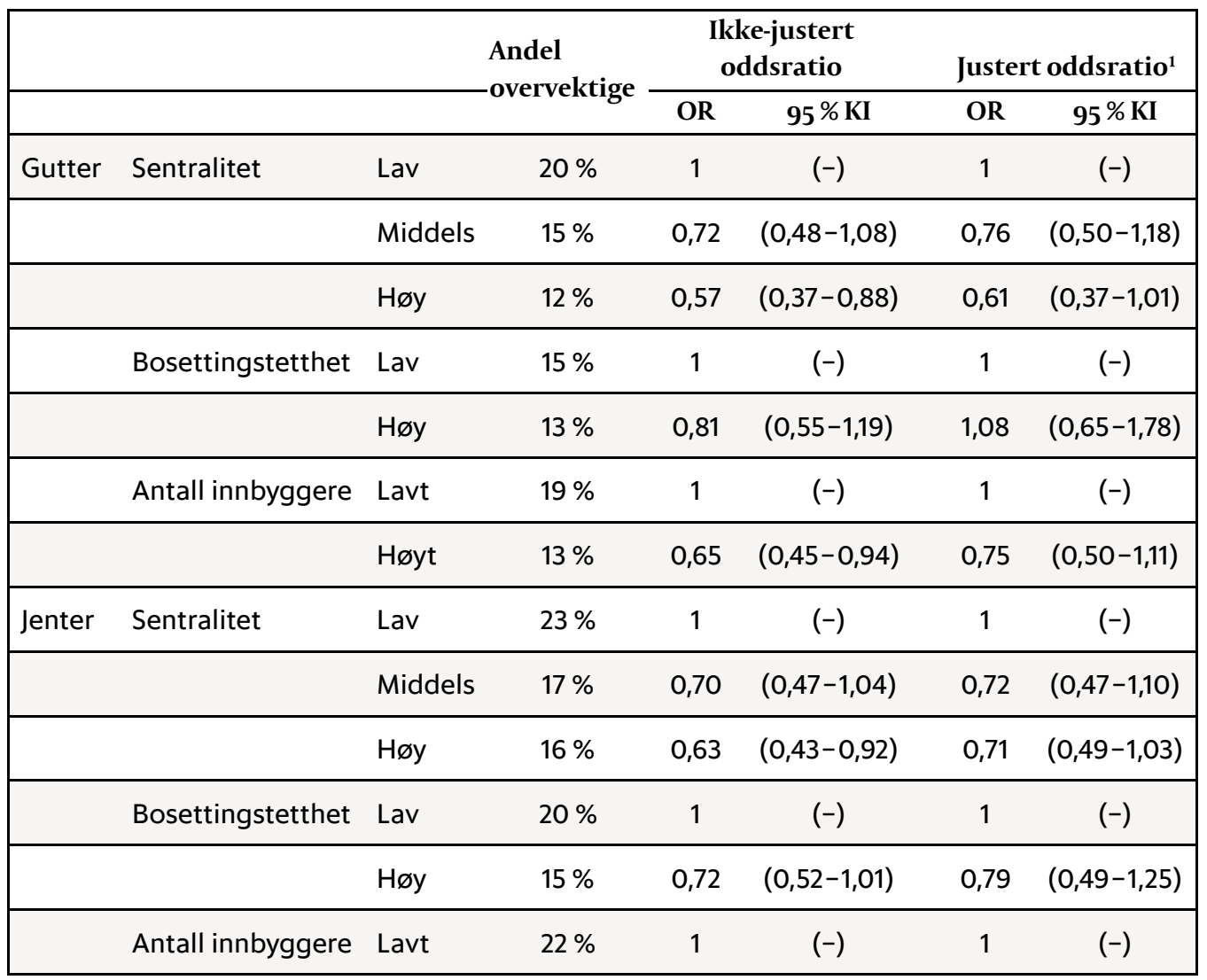




\begin{tabular}{|c|c|c|c|c|c|c|c|}
\hline & & & \multirow{2}{*}{$\begin{array}{l}\text { Andel } \\
\text {-overvektige }\end{array}$} & \multicolumn{2}{|c|}{$\begin{array}{c}\text { Ikke-justert } \\
\text { oddsratio }\end{array}$} & \multicolumn{2}{|c|}{ Justert oddsratio $^{1}$} \\
\hline & & & & OR & $95 \% \mathrm{KI}$ & OR & $95 \% \mathrm{KI}$ \\
\hline & & Høyt & $16 \%$ & 0,70 & $(0,51-0,97)$ & 0,81 & $(0,59-1,11)$ \\
\hline \multirow[t]{7}{*}{ Alle } & Sentralitet & Lav & $21 \%$ & 1 & $(-)$ & 1 & $(-)$ \\
\hline & & Middels & $16 \%$ & 0,71 & $(0,52-0,96)$ & 0,74 & $(0,53-1,02)$ \\
\hline & & Нøу & $14 \%$ & 0,60 & $(0,42-0,85)$ & 0,66 & $\begin{array}{c}(0,46- \\
0,94)\end{array}$ \\
\hline & Bosettingstetthet & Lav & $17 \%$ & 1 & $(-)$ & 1 & $(-)$ \\
\hline & & Нøу & $14 \%$ & 0,77 & $(0,57-1,03)$ & 0,91 & $\begin{array}{c}(0,60- \\
1,40)\end{array}$ \\
\hline & Antall innbyggere & Lavt & $20 \%$ & 1 & $(-)$ & 1 & $(-)$ \\
\hline & & Høyt & $15 \%$ & 0,67 & $(0,51-0,90)$ & 0,77 & $(0,58-1,03)$ \\
\hline [i] & & & & & & & \\
\hline
\end{tabular}

[i] ${ }^{1}$ Justert for gjennomsnittlig inntekt og utdanning i kommunen. Det er ikke justert for alder fordi vi har benyttet aldersspesifikk kategori for BMI. Det er dermed allerede tatt hensyn til barnas alder

Multippel logistisk regresjon viste at når utdanningsnivå og inntekt i kommunen ble kontrollert for, hadde barn i kommuner med høy sentralitet $34 \%$ mindre odds for overvekt sammenliknet med barn i kommuner med lav sentralitet ( $\mathrm{OR}=0,66,95 \% \mathrm{KI}$ o,46-0,94). Vi fant samme tendens for bosettingstetthet og innbyggertall, men her var det ikke statistisk signifikante sammenhenger.

\section{LIVVIDDE OG KOMMUNEEGENSKAPER}

Tabell 3 viser resultater for livvidde. I modellen der utdanning og inntekt i kommunen samt alder var inkludert, var gjennomsnittlig livvidde o,66 cm lavere i kommuner med høy bosettingstetthet sammenliknet med kommuner med lav bosettingstetthet ( $95 \% \mathrm{KI}$ o, O21,31). Bosettingstetthet hadde sammenheng med livvidde bare hos jenter (B:-0,94, 95\% KI$1,77^{--0,11)}$. Sammenhengen mellom livvidde og sentralitet og innbyggertall var ikke statistisk signifikant.

\section{Tabell 3}

Sammenheng mellom livvidde hos 3. klassinger og sentralitet, bosettingstetthet og antall innbyggere fra lineær regresjonsmodell. Barns vekst i Norge 2008, N = 3473 . B = ustandardisert regresjonskoeffisient

\begin{tabular}{|c|c|c|c|c|c|c|c|}
\hline & & & \multirow{2}{*}{$\begin{array}{l}\text { Gjennomsnittlig } \\
\text {-livvidde, cm }\end{array}$} & \multicolumn{2}{|c|}{ Ikke-justert } & \multicolumn{2}{|c|}{ Justert $^{1}$} \\
\hline & & & & B & $95 \% \mathrm{KI}$ & B & $95 \% \mathrm{KI}$ \\
\hline \multirow[t]{4}{*}{ Gutter } & Sentralitet & Lav & 60,0 & 1 & $(-)$ & 1 & $(-)$ \\
\hline & & Middels & 58,9 & $\begin{array}{c}- \\
1,07\end{array}$ & $\begin{array}{c}(-2,32- \\
0,17)\end{array}$ & $\begin{array}{c}- \\
0,57\end{array}$ & $\begin{array}{c}(-1,80- \\
0,66)\end{array}$ \\
\hline & & Нøу & 58,4 & $-1,61$ & $\begin{array}{c}(-2,97-- \\
0,24)\end{array}$ & $\begin{array}{c}- \\
0,72\end{array}$ & $\begin{array}{c}(-2,25- \\
0,82)\end{array}$ \\
\hline & Bosettingstetthet & Lav & 59,4 & 1 & $(-)$ & 1 & $(-)$ \\
\hline
\end{tabular}




\begin{tabular}{|c|c|c|c|c|c|c|c|}
\hline & & & \multirow{2}{*}{$\begin{array}{l}\text { Gjennomsnittlig } \\
\text { livvidde, cm }\end{array}$} & \multicolumn{2}{|c|}{ Ikke-justert } & \multicolumn{2}{|c|}{ Justert $^{1}$} \\
\hline & & & & B & $95 \% \mathrm{KI}$ & B & $95 \% \mathrm{KI}$ \\
\hline & & Нøу & 58,2 & $-1,21$ & $\begin{array}{c}(-2,08-- \\
0,35)\end{array}$ & $-0,41$ & $\begin{array}{c}(-1,32- \\
0,50)\end{array}$ \\
\hline & Antall innbyggere & Lavt & 59,8 & 1 & $(-)$ & 1 & $(-)$ \\
\hline & & Høyt & 58,5 & $\begin{array}{c}- \\
1,32\end{array}$ & $\begin{array}{c}(-2,63-- \\
0,02)\end{array}$ & $\begin{array}{c}- \\
0,42\end{array}$ & $\begin{array}{c}(-1,73- \\
0,89)\end{array}$ \\
\hline \multirow[t]{7}{*}{ Jenter } & Sentralitet & Lav & 58,4 & 1 & $(-)$ & 1 & $(-)$ \\
\hline & & Middels & 58,1 & $\begin{array}{c}- \\
0,24\end{array}$ & $\begin{array}{c}(-1,28- \\
0,8)\end{array}$ & $\begin{array}{c}- \\
0,03\end{array}$ & $\begin{array}{c}(-1,15- \\
1,09)\end{array}$ \\
\hline & & Нøу & 57,6 & $\begin{array}{c}- \\
0,80\end{array}$ & $\begin{array}{c}(-1,77- \\
0,18)\end{array}$ & 0,03 & $(-1,10-1,16)$ \\
\hline & Bosettingstetthet & Lav & 58,4 & 1 & $(-)$ & 1 & $(-)$ \\
\hline & & Нøу & 57,2 & $-1,15$ & $\begin{array}{c}(-1,94-- \\
0,35)\end{array}$ & $\begin{array}{c}- \\
0,94\end{array}$ & $\begin{array}{c}(-1,77-- \\
0,11)\end{array}$ \\
\hline & Antall innbyggere & Lavt & 58,0 & 1 & $(-)$ & 1 & $(-)$ \\
\hline & & Høyt & 57,8 & $-0,2$ & $(-1,19-0,8)$ & 0,70 & $\begin{array}{c}(-0,38- \\
1,78)\end{array}$ \\
\hline \multirow[t]{7}{*}{ Alle } & Sentralitet & Lav & 59,2 & 1 & $(-)$ & 1 & $(-)$ \\
\hline & & Middels & 58,5 & $\begin{array}{c}- \\
0,66\end{array}$ & $\begin{array}{c}(-1,59- \\
0,27)\end{array}$ & $\begin{array}{c}- \\
0,29\end{array}$ & $\begin{array}{c}(-1,27- \\
0,70)\end{array}$ \\
\hline & & Нøу & 58,0 & $-1,21$ & $\begin{array}{c}(-2,17-- \\
0,25)\end{array}$ & $\begin{array}{c}- \\
0,34\end{array}$ & $\begin{array}{c}(-1,51- \\
0,82)\end{array}$ \\
\hline & Bosettingstetthet & Lav & 58,9 & 1 & $(-)$ & 1 & $(-)$ \\
\hline & & Нøу & 57,7 & $-1,19$ & $\begin{array}{c}(-1,85-- \\
0,54)\end{array}$ & $\begin{array}{c}- \\
0,66\end{array}$ & $\begin{array}{c}(-1,31-- \\
0,02)\end{array}$ \\
\hline & Antall innbyggere & Lavt & 58,9 & 1 & $(-)$ & 1 & $(-)$ \\
\hline & & Høyt & 58,2 & $\begin{array}{c}- \\
0,75\end{array}$ & $\begin{array}{c}(-1,66- \\
0,15)\end{array}$ & 0,16 & $\begin{array}{c}(-0,79- \\
1,11)\end{array}$ \\
\hline [i] & & & & & & & \\
\hline
\end{tabular}

[i] ]Justert for alder og gjennomsnittlig inntekt og utdanning i kommunen

\section{BMI OG KOMMUNEEGENSKAPER}

Gjennomsnittlig BMI var statistisk signifikant forskjellig i gruppen med lav og høy sentralitet, hhv. 16,99 kg/m² og 16,52 kg/m², lav og høy bosettingstetthet, hhv. 16,77 kg/m² og $16,51 \mathrm{~kg} / \mathrm{m}^{2}$ og lavt og høyt innbyggertall, hhv. $16,95 \mathrm{~kg} / \mathrm{m}^{2}$ og $16,57 \mathrm{~kg} / \mathrm{m}^{2}$ (data ikke vist).

I ujusterte analyser var høy BMI signifikant assosiert med lav sentralitet, lav bosettingstetthet og lavt innbyggertall. I den justerte lineære regresjonsmodellen var sammenhengene ikke lenger signifikante (data ikke vist).

\section{Diskusjon}


Vårt hovedfunn var at andelen barn med overvekt er lavere i kommuner med høy grad av sentralitet sammenliknet med kommuner med lav grad av sentralitet, og vi ser de samme tendensene i sammenhengen mellom livvidde og bosettingstetthet. Vi mener denne kunnskapen om sammenheng mellom overvekt og urbanitet er viktig i arbeidet for å forebygge overvekt i vår barnebefolkning. I likhet med vår studie er det i andre studier blitt observert høyere gjennomsnittlig BMI og høyere andel med overvekt og fedme blant barn og unge i småbyer eller på landet sammenliknet med barn i byer $(\underline{20}, \underline{23}, \underline{24})$. Etter det vi vet, har ingen tidligere sammenliknet overvekt hos barn i urbane og rurale områder i Norge ved bruk av objektivt målte data. Livvidde hos barn er heller ikke blitt undersøkt i en slik kontekst. Vi har ingen grenseverdier for livvidde hos barn (7.), og vi kan derfor ikke vurdere barnas helserisiko ut ifra denne. Det er likevel interessant at også barnas livvidde er lavere i kommuner med høy grad av urbanitet.

Vi fant signifikante sammenhenger mellom utfallsvariablene og kommuneegenskaper i de ujusterte analysene. Noen av effektene ble mindre og ikke-signifikante når vi kontrollerte for inntekts- og utdanningsnivå i kommunen. De tre urbanitetsvariablene er høyt korrelert med økonomi og utdanning, og det er derfor vanskelig å skille hva som er en direkte effekt av kommunenes urbanitetsnivå og hva som er knyttet til inntekt og utdanning.

En tidligere studie viste en gjennomsnittlig BMI hos norske niåringer på $17,3 \mathrm{~kg} / \mathrm{m}^{2}$ for gutter og 17,5 kg/m² for jenter (31). Dette er noe høyere enn gjennomsnittet på 16,6 kg/m² blant våre åtteåringer. Andel barn med overvekt var i vår studie også noe lavere enn tidligere studier av barn i Norge (므, 21, 31). Gjennomsnittlig livvidde i vårt utvalg var 58,3 $\mathrm{cm}$. Kolle og medarbeidere fant en gjennomsnittlig livvidde på $64,7 \mathrm{~cm}$ i en studie av niåringer i 4. klasse i Oslo (므). En aldersforskjell på ett år har antakelig betydning for disse forskjellene.

Sammenhengen mellom urbanitet og overvekt kan være mediert av fysisk aktivitet (32). Flø og medarbeidere peker på at inaktivisering av bygdebarn pga. bil- og busskjøring til skole og fritidsaktiviteter kan være en mulig forklaring på forskjellene mellom urbane og rurale områder (므). Daglig aktivitet, som å sykle og gå til skole og fritidsaktiviteter, har betydning for barns totale aktivitetsnivå (33). At barn i rurale områder har begrensede muligheter til dette på grunn av stor avstand eller utrygt trafikkmiljø, kan ha negativ innvirkning på aktivitetsnivået (34).

Denne forklaringen støttes av en norsk undersøkelse av barns bomiljø som viste at urbane barn har høyere nivå av fysisk aktivitet enn andre barn fordi de deltar i flere aktiviteter og $\mathrm{i}$ større grad går til skole og fritidsaktiviteter (34.). Dette bekreftes i en rapport fra 2011 der Transportøkonomisk institutt viste at flere barn i urbane områder gikk og syklet til skolen sammenliknet med barn i rurale områder (35).

Kosthold er også en viktig faktor (11), og man har sett forskjeller i kosthold mellom urbane og rurale områder (3므).

Kunnskap om betydningen av urbanitet for utvikling av overvekt og fedme i barndommen er viktig i arbeidet for å forebygge overvekt. I planarbeid vil dette være nyttig både lokalt, regionalt og nasjonalt. Årsakene til overvekt er multifaktorielle, og det er viktig at forebyggende tiltak rettes mot samfunnet som helhet $(\underline{11}, \underline{18})$.

Globale faktorer bidrar til utvikling av overvekt, og lokal påvirkning avgjør hvor stor

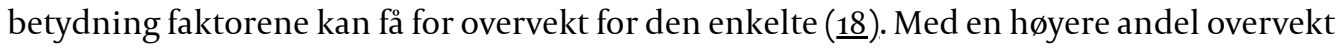
hos barn i rurale områder, bør oppmerksomheten rettes mot de faktorene i bygdebarnas nærmiljø som kan bidra til overvekt.

STYRKER OG SVAKHETER

Vi hadde et representativt utvalg med høy svarprosent, og barna ble objektivt målt. Opplæring av helsesøstrene og kontroll av måleinstrumenter begrenser risikoen for målefeil. Kun $1 \% ø n s k e t$ ikke å delta i studien. Dette reduserer betydningen av mulig seleksjonsskjevhet. At $10 \%$ ikke var til stede på skolen måledagen eller ikke svarte på 
purring på samtykke, gjør at denne muligheten likevel må holdes åpen. Vi kan ikke utelukke at relevante egenskaper ved barna som ikke var til stede på skolen skiller dem fra barna som var til stede.

Ut ifra denne studien kan vi ikke si noe om årsaker til overvekt, men kun om assosiasjoner mellom forklaringsvariabler og utfall. Vi har ikke sosioøkonomiske data på foreldrene, og har av den grunn kontrollert for utdanning og inntekt på kommunenivå. I oppfølgingen av Barns vekst $i$ Norge som gjennomføres i 2010 og 2012, vil individdata for sosioøkonomi være tilgjengelig.

De uavhengige variablene i analysene hang nøye sammen, og dette gjør modelltilpasning problematisk. Variablene for utdanning og inntekt var imidlertid blant de lavest korrelerte, og vi valgte derfor å inkludere begge variablene i de justerte analysene fordi disse ville gi ulik informasjon om sosioøkonomisk status. Det kan også være ukjente konfunderende variabler vi ikke har kontrollert for.

\section{Konklusjon}

I vår studie fant vi at andelen overvektige og gjennomsnittlig livvidde avtar med økende urbanitet. Etter kontroll for effekten av utdanning- og inntektsnivå i kommunen, var sentralitet og bosettingstetthet signifikante forklaringsvariabler for henholdsvis overvekt og livvidde. Det gjenstår å undersøke helseeffekter av de forskjellene vi har funnet. Det vil også være av betydning å undersøke hvordan sammenhengene mellom overvekt og urbanitet faller ut korrigert med individdata for sosioøkonomisk status. Det er viktig å få mer kunnskap om det er spesielle miljøfaktorer som påvirker utviklingen av overvekt blant barn på landsbygda.

Barns vekst $i$ Norge er delfinansiert av Helsedirektoratet. Artikkelen er basert på førsteforfatters mastergradsoppgave i folkehelsevitenskap ved Universitetet for miljø- og biovitenskap (1).

\section{LITTERATUR}

1. Heyerdahl N. Kroppsmasseindeks, overvekt og fedme hos barn i urbane og rurale områder i Norge - en studie blant tredjeklassinger. Ås: Institutt for matematiske realfag og teknologi, Universitetet for miljø- og biovitenskap, 2011.

2. Wang Y, Lobstein T. Worldwide trends in childhood overweight and obesity. Int J Pediatr Obes 2006; 1: 11-25. [PubMed] [CrossRef]

3. Júlíusson PB, Roelants M, Eide GE et al. Overweight and obesity in Norwegian children: secular trends in weight-for-height and skinfolds. Acta Paediatr 2007; 96: 1333-7. [PubMed] [CrossRef]

4. Lissner L, Sohlström A, Sundblom E et al. Trends in overweight and obesity in Swedish schoolchildren 1999-2005: has the epidemic reached a plateau? Obes Rev 2010; 11: 553-9. [PubMed] [CrossRef]

5. Stamatakis E, Wardle J, Cole TJ. Childhood obesity and overweight prevalence trends in England: evidence for growing socioeconomic disparities. Int J Obes (Lond) 2010;34: 41-7. [PubMed] [CrossRef]

6. Kolle E, Steene-Johannessen J, Holme I et al. Secular trends in adiposity in Norwegian 9-year-olds from 1999-2000 to 2005. BMC Public Health 2009; 9:389. [PubMed] [CrossRef]

7. Lobstein T, Baur L, Uauy R. Obesity in children and young people: a crisis in public health. Obes Rev 2004; 5 (suppl 1): 4-104. [PubMed] [CrossRef]

8. Maffeis C, Banzato C, Talamini G. Waist-to-height ratio, a useful index to identify high metabolic risk in overweight children. J Pediatr 2008; 152: 207-13. [PubMed] [CrossRef] 
9. Janssen I, Heymsfield SB, Allison DB et al. Body mass index and waist circumference independently contribute to the prediction of nonabdominal, abdominal subcutaneous, and visceral fat. Am J Clin Nutr 2002; 75: 683-8. [PubMed]

10. Maffeis C, Grezzani A, Pietrobelli A et al. Does waist circumference predict fat gain in children? Int J Obes Relat Metab Disord 2001; 25: 978-83. [PubMed] [CrossRef]

11. World Health Organization. Report of a Joint WHO/FAO Expert Consultation. Diet, nutrition and the prevention of chronic diseases 2003. WHO Technical Report Series nr. 916. Genève: World Health Organization, 2003.

12. Whitaker RC, Wright JA, Pepe MS et al. Predicting obesity in young adulthood from childhood and parental obesity. N Engl J Med 1997; 337: 869-73. [PubMed] [CrossRef]

13. Wang YC, McPherson K, Marsh T et al. Health and economic burden of the projected obesity trends in the USA and the UK. Lancet 2011; 378: 815-25. [PubMed] [CrossRef]

14. Ebbeling CB, Pawlak DB, Ludwig DS. Childhood obesity: public-health crisis, common sense cure. Lancet 2002; 360: 473-82. [PubMed] [CrossRef]

15. Katz DL. Unfattening our children: forks over feet. Int J Obes (Lond) 2011;35:33-7. [PubMed] [CrossRef]

16. Wangensteen T, Undlien D, Tonstad S et al. Genetiske årsaker til fedme. Tidsskr Nor Lægeforen 2005; 125:3090-3. [PubMed]

17. Grøholt EK, Stigum H, Nordhagen R. Overweight and obesity among adolescents in Norway: cultural and socio-economic differences. J Public Health (Oxf) 2008; 30: 258-65. [PubMed] [CrossRef]

18. Swinburn BA, Sacks G, Hall KD et al. The global obesity pandemic: shaped by global drivers and local environments. Lancet 2011; 378: 804-14. [PubMed] [CrossRef]

19. Aeberli I, Ammann RS, Knabenhans M et al. Decrease in the prevalence of paediatric adiposity in Switzerland from 2002 to 2007. Public Health Nutr 2010; 13: 806-11. [PubMed] [CrossRef]

20. Sjöberg A, Moraeus L, Yngve A et al. Overweight and obesity in a representative sample of schoolchildren - exploring the urban-rural gradient in Sweden. Obes Rev 2011; 12:305-14. [PubMed] [CrossRef]

21. Júlíusson PB, Eide GE, Roelants M et al. Overweight and obesity in Norwegian children: prevalence and socio-demographic risk factors. Acta Paediatr 2010; 99: 900-5. [PubMed] [CrossRef]

22. Vilimas K, Glavin K, Donovan ML. Overvekt hos åtte- og 12-åringer i Oslo i 2004. Tidsskr Nor Lægeforen 2005; 125:3088-9. [PubMed]

23. Ekblom OB, Oddsson K, Ekblom BT. Prevalence and regional differences in overweight in 2001 and trends in BMI distribution in Swedish children from 1987 to 2001. Scand J Public Health 2004; 32: 25763. [PubMed] [CrossRef]

24. Ismailov RM, Leatherdale ST. Rural-urban differences in overweight and obesity among a large sample of adolescents in Ontario. Int J Pediatr Obes 2010; 5:351-6o. [PubMed] [CrossRef]

25. Liu JH, Bennett KJ, Harun $\mathrm{N}$ et al. Urban-rural differences in overweight status and physical inactivity among US children aged 10-17 years. J Rural Health 2008; 24: 407-15. [PubMed] [CrossRef]

26. Flø BE, Heggem R, Rye JF et al. Bygdebarnas fedme. Aftenposten 23.2.2008.

27. Hovengen R, Meisfjord J, Biehl A et al. Barns vekst i Norge 2008. Oslo: Folkehelseinstituttet, 2009.

28. Cole TJ, Bellizzi MC, Flegal KM et al. Establishing a standard definition for child overweight and obesity worldwide: international survey. BMJ 2000;320: 1240-3. [PubMed] [CrossRef]

29. International Obesity Taskforce. IOTF History. www.iaso.org/iotf/aboutiotf/iotfhistory/ (29.4.2011).

30. Statistisk sentralbyrå. Sentralitet 2008. www3.ssb.no/stabas/ItemsFrames.asp?

$\mathrm{ID}=5285601 \&$ Language $=\mathrm{nb}(15 \cdot 9 \cdot 2010)$.

31. Anderssen SA, Kolle E, Steene-Johannessen J et al. Fysisk aktivitet blant barn og unge i Norge: en kartlegging av aktivitetsnivå og fysisk form hos 9- og 15-åringer. Oslo: Helsedirektoratet, 2008.

32. Nordic Nutrition Recommendations. Intergrating nutrition and physical activity. 4. utg. København: Nordic Council of Ministers, 2004.

33. Bratteby LE, Sandhagen B, Lötborn M et al. Daily energy expenditure and physical activity assessed by an activity diary in 374 randomly selected 15-year-old adolescents. Eur J Clin Nutr 1997; 51: 592-6oo. [PubMed] [CrossRef]

34. Fyhri A, Hjorthol R. Barns fysiske bomiljø, aktiviteter og daglige reiser. Rapport nr. 869/2006. Oslo: Transportøkonomisk institutt, 2006. 
35. Fyhri A, Elvebakk B. Barns daglige reiser i Oslo, Akershus og Buskerud. Rapport nr. 1139/2011. Oslo: Transportøkonomisk institutt, 2011.

36. Simen-Kapeu A, Kuhle S, Veugelers PJ. Geographic differences in childhood overweight, physical activity, nutrition and neighbourhood facilities: implications for prevention. Can J Public Health 2010; 101: 128-32. [PubMed]

Publisert: 15. mai 2012. Tidsskr Nor Legeforen. DOI: 10.4045/tidsskr.11.1078

Mottatt 26.9. 2011, første revisjon innsendt 14.11. 2011, godkjent 8.3. 2012. Medisinsk redaktør Siri Lunde. (C) Tidsskrift for Den norske legeforening 2023. Lastet ned fra tidsskriftet.no 26. april 2023. 